\title{
The Military and State Secrets Privilege: Protection for the National Security or Immunity for the Executive?
}

A litigant's need for information is often at odds with individual and social needs for secrecy. American courts accommodate the resulting tension by establishing privileges to protect certain information from otherwise broad discovery rights. ${ }^{1}$ As with all compromises, some interests are sacrificed. This Note argues that for at least one privilege-the privilege for military and state secrets-the wrong compromise has been struck. Because significant litigant interests have gone unconsidered, undue deference is paid to secrecy needs.

The military and state secrets (state secrets) privilege has been a longstanding but infrequently invoked privilege. ${ }^{2}$ Recently, however, the federal executive increasingly has used the privilege to bar discovery in suits that allege illegal government surveillance of political activists. ${ }^{3}$ Frequently, present judicial treatment inappropriately permits privilege claims to undermine litigants' discovery rights and vitiates constitutional and statutory constraints on executive powers. For evaluating and responding to these privilege claims, this Note suggests a set of alternative procedures that would improve the ability of courts to protect the individual rights and the congressional policies at stake without jeopardizing the executive's legitimate secrecy interests.

\section{The State Secrets Privilege}

The state secrets privilege permits the executive to withhold evidence if disclosure would prejudice the national security. In a series of recent

1. See FED R. GIV. P. 26(b)(1) ("Parties may obtain discovery regarding any matter, not privileged, which is relevant to the subject matter involved in the pending action.") For the purposes of Rule 26, courts define "privileged" in terms of the evidentiary privileges. See, e.g., Jabara v. Kelley, 75 F.R.D. 475, 481 (E.D. Mich. 1977); see E. CLEARY, MCCORMICK'S HANDBOOK OF THE LAW OF EVIDENCE 151-432 (2d ed. 1972) (discussing law of privileges).

2. See, e.g., United States v. Reynolds, 345 U.S. 1, 6-7 (1953) (discussing origin of privilege).

3. See, e.g., Halkin v. Helms, 598 F.2d 1 (D.C. Cir. 1978) (suit by anti-Vietnam war activists against officials of Central Intelligence Agency (CIA) and National Security Agency (NSA) for surveillance and disruption of private and political activity); Alliance to End Repression v. City of Chicago, 91 F.R.D. 182 (N.D. Ill. 1981) (suit by political organizations and members alleging unlawful infiltration, surveillance, and harrassment); Socialist Workers Party v. Attorney Gen., 463 F. Supp. 515 (S.D.N.Y. 1978) (same); National Lawyers Guild v. Attorney Gen., No. 77-0999 (S.D.N.Y. Mar. 1, 1977) (same); Jabara v. Kelley, 75 F.R.D. 475 (E.D. Mich. 1977) (suit by supporters of Palestinians alleging unconstitutional and illegal surveillance by Federal Bureau of Investigation (FBI) and local police); Kinoy v. Mitchell, 67 F.R.D. 1 (S.D.N.Y. 1975) (suit by civil rights attorney alleging surveillance of political, professional, and personal activities). 
cases, this privilege has been invoked in a manner that seriously burdens discovery rights and impairs constraints on executive powers.

\section{A. The History and Current Use of the Privilege}

The state secrets privilege is a common-law evidentiary privilege that allows the government to resist discovery of information that if disclosed would injure the national defense or foreign policy. ${ }^{4}$ The privilege permits the executive to withhold information from litigants despite its relevance to matters before the courts. The information protected usually relates to military affairs, but has also included information that concerned peacetime foreign policy and foreign intelligence activities. ${ }^{5}$

\section{The United States v. Reynolds Standard}

The exact origins of the state secrets privilege are unclear. Although its heritage in American jurisprudence can be traced to Aaron Burr's trial for treason, ${ }^{6}$ its modern use stems from English precedent established during

4. See, e.g., United States v. Reynolds, 345 U.S. 1, 6-7 (1953); see E. CLEARY, supra note 1, at 229-31.

Congress rejected a proposal to include in the Federal Rules of Evidence a rule that would govern use of the privilege. Many representatives had expressed concern that the President would exploit the rule to curtail legislative investigations and litigants' discovery rights. See $2 \mathrm{~J}$. WEINSTEIN \& M. BERGER, WEINSTEIN'S EVIDENCE I 501[02], at 501-17 (1979); cf. FED. R. EVID. 501 (general rule does not specifically regulate use of privilege). The privilege is not limited to barring forced disclosure through discovery. See Firth Stirling Steel Co. v. Bethlehem Steel Co., 199 F. 353, 355 (E.D. Pa. 1912) (exhibits expunged from record because they revealed secrets of military value). Certain statutes also authorize withholding of specific types of national security information. See, e.g., Atomic Energy Act of 1954, § 142, 42 U.S.C. § 2162 (1976) (classification of atomic secrets); Nuclear Regulatory Commission Appropriations Authorization, 1980, § 207, 42 U.S.C.A. $\$ 2167$ (Supp. 1981) (control of information relating to Nuclear Regulatory Commission licenses); see $8 \mathrm{~J}$. WIGMORE, EVIDENCE 796 (rev. 1961) (listing statutes).

The state secrets privilege is similar to the classified information exemption of the Freedom of Information Act (FOIA). 5 U.S.C. $§ 552(b)(1)$ (1976) (exempting from disclosure information that is properly classified and must remain secret in interest of national security). Both protect against compelled disclosure of information relating to national security. The FOIA creates a general public right of access to government-held information without regard to need. Id. $\S 552$ (a) (disclosure to "any person"); see McClelland v. Andrus, 606 F.2d 1278, 1287 n.54 (D.C. Cir. 1979) (comparing disclosure under discovery rules and FOIA). Litigants, by contrast, often have a compelling need for discovery.

5. See, e.g., United States v. Reynolds, 345 U.S. 1, 10 (1953) (details of recently developed aircraft radar); Farnsworth Cannon, Inc. v. Grimes, 635 F.2d 268, 269 (4th Cir. 1980) (military related contracts; military comployee's job responsibilities); Halkin v. Helms, 598 F.2d 1, 8 (D.C. Cir. 1978) (interception of plaintiff' overseas communications); Heine v. Raus, 399 F.2d 785, 787-88 (4th Cir. 1968) (employment of defendant CIA agent operating in United States); Attorney Gen. v. Irish People, Inc., 502 F. Supp. 63, 64-65 (D.D.C. 1980) (diplomatic communications); Republic of China v. National Union Fire Ins. Co., 142 F. Supp. 551, 553, 556 (D. Md. 1956) (memoranda of conversations between American and British officials concerning recognition of sovereign immunity of Peoples' Republic of China).

6. United States v. Burr, 25 F. Cas. 30, 37 (C.C.D. Va. 1807) (No. 14,692d). In upholding Burr's right to subpoena correspondence between President Jefferson and General Wilkinson, Chief Justice Marshall, sitting as Circuit Justice, stated that the court would withhold any irrelevant information that would endanger the public safety if disclosed. Id.; see R. BERGER, EXECUTIVE PRIVILEGE 
World War Two.' United States v. Reynolds ${ }^{8}$ contains the United States Supreme Court's most thorough discussion of the privilege. Reynolds was a suit under the Federal Tort Glaims Act (FTCA) ${ }^{9}$ for the wrongful deaths of three civilian observers in the crash of an Air Force plane that was testing secret electronic equipment. ${ }^{10}$ The plaintiffs, widows of the deceased, sought production of the Air Force accident report. ${ }^{11}$ The Secretary of the Air Force asserted that the report was privileged and offered instead to produce the witnesses who had testified at the investigation. ${ }^{12}$ The Supreme Court, in reversing the district ${ }^{13}$ and circuit courts, ${ }^{14}$ upheld the privilege claim. ${ }^{15}$

Drawing parallels between the facts of this case and the British and American cases in which the privilege was invoked, the Reynolds Court set out several procedural requirements. ${ }^{16}$ The privilege belongs to the executive; ${ }^{17}$ only a cabinet level officer, after personally reviewing the material, may assert it. ${ }^{18}$ The claim may be made in open court or by in camera presentation. The officer may support the claim by submitting the material itself or affidavits describing it, or by testifying to its privileged

215-24 (1974).

7. See United States v. Reynolds, 345 U.S. 1, 7 (1953) (citing Duncan v. Cammel, Laird \& Co., 1942 A.C. 624 (upholding claim of privilege for submarine plans)).

8. 345 U.S. 1 (1953).

9. 28 U.S.C. $\$ \S 1346,2671$ (1976).

10. See United States v. Reynolds, 345 U.S. 1, 3 (1953).

11. Id.

12. Id. at 4-5.

13. See Brauner v. United States, 10 F.R.D. 468 (E.D.Pa. 1950).

14. See Reynolds v. United States, 192 F.2d 987, 997 (3d Cir. 1951).

15. See United States v. Reynolds, 345 U.S. 1, 5, 12 (1953).

16. See id. at 7 (discussing method of invocation of privilege in British courts). The Reynolds opinion also cited several American precedents for the privilege. See id.

17. Id. The privilege is different from the "executive privilege," which protects the confidentiality of communications among certain executive officials. See United States v. Nixon, 418 U.S. 683, 703-16 (1974); Association for Women in Science v. Califano, 566 F.2d 339, 343 (D.C. Cir. 1977); R. BERGER, supra note 6, at 209-33.

18. United States v. Reynolds, 345 U.S. at 8; see In re Eisenberg, 654 F.2d 1107, 1110 n.5 (5th Cir. 1981). Although courts consistently apply the personal review requirement, see, e.g., United States v. Felt, 502 F. Supp. 74, 75-76 (D.D.C. 1980) (affidavits asserting privilege state affiants' personal familiarity with documents); Kinoy v. Mitchell, 67 F.R.D. 1, 9-10 (S.D.N.Y. 1975) (personal review by cabinet level official is not mere technical requirement); $c$. Clift v. United States, 597 F.2d 826, 828-29 (2d Cir. 1979) (reluctantly upholding privilege without assertion by Secretary of Defense; personal review unnecessary because statute criminalized disclosure of material sought), they do not question the thoroughness of review by the officer, see, e.g., Jabara v. Kelley, 75 F.R.D. 475, 487 (E.D. Mich. 1977) (court does not doubt that Attorney General gave careful consideration to privilege claim). Commentators have criticized this presumption of careful, high-level consideration as unrealistic. E.g., Berger \& Krash, Government Immunity from Discovery, 59 YALE L.J. I451, 1464 (1950) (actual decision to deny discovery often made by subordinate employees). Affidavits filed in one case indicate that the official who formally asserts the claim usually does so after only perfunctory review of a subordinate's decision. See Affidavit and Formal Claim of Privilege of Attorney General Griffin Bell, Kinoy v. Mitchell, No. 70-5698 (S.D.N.Y., Feb. 9, 1979) (asserting claim of privilege after review of subordinate's recommendations) (on file with Yale Law Journal). 
status. ${ }^{19}$ Although the party seeking discovery may rebut the claim of privilege, the court may require the party to make this rebuttal without access to the material, to the affidavits, or to the testimony concerning it. ${ }^{20}$ The Reynolds court stated that the judiciary must be the final arbiter of a privilege claim. ${ }^{21}$ This independent judgment serves as a check on executive caprice and self-interest, and preserves judicial autonomy on evidentiary matters. ${ }^{22}$

\section{The Prejudicial Impact Test}

The lower courts, however, have acted cautiously when reviewing privilege claims. ${ }^{23}$ They have applied a prejudicial impact test ${ }^{24}$ that asks only whether there is a reasonable danger that discovery will disclose informa-

19. In Reynolds, the Secretary, in open court, disclosed the nature of the material and the reasons for withholding it. 345 U.S. at 4-5. More recently, the executive has relied extensively on in camera, ex parte affidavits or testimony. Sec, e.g., Farnsworth Cannon, Inc. v. Grimes, 635 F.2d 268, 269 (4th Cir. 1980); Halkin v. Helms, 598 F.2d 1, 9 (D.C. Cir. 1978); United States v. Felt, 502 F. Supp. 74, 75-76 (D.D.C. 1980). The courts are authorized to compel production of the material for in camera, ex parte review, but they exercise this authority with restraint. See, e.g., American Civil Liberties Union v. Brown, 619 F.2d 1170, 1173 (7th Cir. 1980) (in camera inspection particularly appropriate in domestic security claims); Jabara v. Kelley, 75 F.R.D. 475, 486 (E.D. Mich. 1977) (ordering in camera inspection when evidence is crucial to plaintiff's case and privilege claim by affidavit is otherwise unsubstantiated). Such review presents dangers both to the executive and to the litigants because it invites security breaches and risks, and prejudices the court with unchallenged submissions. See infra notes 72, 89-92 (proposing procedures to protect against these dangers).

20. See, e.g., Sigler v. LeVan, 485 F. Supp. 185, 193-94 (D. Md. 1980) (denying plaintiffs counsel opportunity to participate in in camera review of affidavit asserting privilege); Jabara v. Kelley, 75 F.R.D. 475, 486 (E.D. Mich. 1977) (denying plaintiff and counsel access to classified in camera exhibits that supported privilege claim). Courts have recognized that ex parte determinations hamper evaluation of claims because the court must act without insights from the party at interest. Halkin v. Helms, 598 F.2d 1, 6-7 (D.C. Cir. 1978). Nonetheless, they encourage such procedures when necessary to protect national security. Id. The Supreme Court indicated in United States v. Nixon, 418 U.S. 683 (1974), that the district court, in performing its in camera review of allegedly privileged material, may seek the aid of counsel for the party seeking discovery. Id. at $715 \mathrm{n}$.21. At least one court has held this statement inapplicable to determinations of the state secrets privilege. See Halkin v. Helms, 598 F.2d l, 7 (D.C. Cir. 1978) (state secrets not analogous to presidential communications; special prosecutor authorized to participate in camera in Nixon was government employee).

21. 345 U.S. at 9.

22. Id. at 9-10; see $8 \mathrm{~J}$. WIGMORE, supra note 4 , at 810 (judicial check necessary to avoid privilege as shield for official wrongdoing).

23. See, e.g., Halkin v. Helms, 598 F.2d 1, 7, 9 (D.C. Cir. 1978) (courts should accord " utmost deference" "to state secrets privilege claims) (quoting United States v. Nixon, 418 U.S. 683, 710 (1974)); Sigler v. LeVan, 485 F. Supp. 185, 194 (D. Md. 1980) (same).

24. Although the courts do not use the phrase, "prejudicial impact test," the term reflects their standard of review. "Prejudicial impact" is adopted from the phrase, "prejudice the public interest and the national security," often used by the executive in its privilege claims. Jabara v. Kelley, 75 F.R.D. 475, 483 (E.D. Mich. 1977); see Alliance to End Repression v. DiLeonardi, No. 74-3268 (N.D. Ill. Dec. 5, 1979) ("[D]isclosure would have a prejudicial impact on the relations of the United States with a foreign power") (quoting affidavit of Attorney General); Affidavit and Formal Claim of Privilege of Attorney General Griffin Bell at 4, Kinoy v. Mitchell, No. 70-5698 (S.D.N.Y. Feb. 9, 1979) ("Disclosure would have a prejudicial impact on the foreign relations of the United States") (on file with Yale Law Journal). 
tion prejudicial to national security. ${ }^{25}$ The prejudicial impact test provides flexible and broad protection for security interests.

The courts have not developed a precise definition of "national security," but consider it a generic term that covers a wide range of interests. ${ }^{26}$ This allows the executive to protect new kinds of information as the nature of overseas threats changes.

In addition, the "reasonable danger" threshold refers only to the likelihood that the material sought contains information that, if disclosed, might harm the national security. ${ }^{27}$ "Reasonable danger" does not refer to the likelihood of any harm actually occurring. This standard does not evaluate the material's sensitivity; that is, the danger reasonably likely to attend disclosure. ${ }^{28}$ The courts have provided the same protection to information that merely threatens to disrupt the conduct of foreign policy as they have provided to information that poses grave threats to military security. ${ }^{29}$

Finally, the courts have not required the executive to assert its security interests consistently or evenhandedly. The executive has been permitted to withhold information from litigants in one suit while making similar information available elsewhere. ${ }^{30}$

Unlike other government privileges-such as the executive communica-

25. See United States v. Felt, 502 F. Supp. 74, 75 (D.D.C. 1980) (disclosure would adversely affect national interest); Sigler v. LeVan, 485 F. Supp. 185, 195 (D. Md. 1980) (disclosure would damage national security); Jabara v. Kelley, 75 F.R.D. 475, 484 (E.D. Mich. 1977) (" "C]ompulsion of the evidence will expose military matters which, in the interest of national security, should not be divulged." ") (quoting United States v. Reynolds, 345 U.S. 1, 11 (1953).

26. See, e.g., New York Times v. United States, 403 U.S. 713, 739 (1971) ("national defense" is generic term not susceptible to precise definition); Gorin v. United States, 312 U.S. 19, 28 (1941) (same); Zagel, The State Secrets Privilege, 50 MiNN. L. REV. 875, 880-85 (1966) (evaluating national defense related secrets requires case by case handling and lacks standardized criteria); Note, National Security and the Amended Freedom of Information Act, 85 YALE L.J. 401, 409-15 (1976) ("national security" is concept concerned with intangibles and uncertainties not reducible to concrete definitions).

27. See Halkin v. Helms, 598 F.2d 1, 9-10 (D.C. Cir. 1978); Jabara v. Kelley, 75 F.R.D. 475, 483 (E.D. Mich. 1977).

28. The courts ordinarily do not require any threshold showing of quantity or quality of danger for information to qualify as privileged. Rather, they give the utmost deference to the executive's claim that information "can be useful information to a sophisticated intelligence analyst," even if the utility or expected danger has not been shown to the court. See American Civil Liberties Union v. Brown, 619 F.2d 1170, 1177 (7th Cir. 1980) (Pell, J., dissenting); Halkin v. Helms, 598 F.2d 1, 8-9 (D.C. Cir. 1978). This deference is necessary, some judges argue, because bits of information that appear innocuous to the untrained judicial cye can be of great value to intelligence agents. See American Civil Liberties Union v. Brown, 619 F.2d 1170, 1177 (7th Cir. 1980) (Pell, J., dissenting); Halkin v. Helms, 598 F.2d 1, 8-9 (D.C. Cir. 1978). One member of the Court of Appeals for the District of Columbia has criticized the process as "the willing suspension of disbelief." Id. at 18 (Bazelon, J., dissenting).

29. Compare United States v. Reynolds, 345 U.S. 1, 10 (1953) (protection of newly developed electronic equipment with military application) with Republic of China v. National Union Fire Ins. Co., 142 F. Supp. 551, 554-55 (D. Md. 1956) (avoidance of exacerbation of tensions arising from British recognition of Peoples' Republic of China).

30. See Halkin v. Helms, 598 F.2d 1, 9 (D.C. Cir. 1978) ("The government is not estopped from concluding in one case that disclosure is permissible while in another case it is not.") 
tions privilege ${ }^{31}$ or the informer's privilege, ${ }^{32}$ which are qualified ${ }^{33}$-the state secrets privilege is absolute. The courts never balance the interests in disclosure against the interests in secrecy. ${ }^{34} \mathrm{~A}$ party's interest in discovery is relevant only to the degree of scrutiny that the courts accord a privilege claim. A court may require in camera inspection to sustain a claim against information crucial to a party's case. ${ }^{35}$ When the information is only tangentially relevant, by contrast, an affidavit that asserts the need for secrecy may suffice. ${ }^{36}$ The standard for upholding the state secrets privilege, however, is the same in all circumstances. As long as it is reasonably likely that discovery will disclose information prejudicial to national security, even the most compelling necessity cannot overcome the privilege. ${ }^{37}$

\section{The Effects of a Valid Privilege Claim}

The courts ordinarily respond to a privilege claim simply by ordering or denying discovery, although in certain circumstances, the courts may take additional action. When the courts uphold the privilege in a government-initiated criminal prosecution, they dismiss the charge if the loss of evidence deprives the defendant of a fair trial. ${ }^{38}$ When the executive defends, however, it faces no similar choice between safeguarding national security and furthering other interests through the litigation. In these circumstances, the courts act as if the privileged information did not exist, even if this is fatal to the plaintiff's suit. ${ }^{39}$

To justify this asymmetry-the executive may benefit from the privilege when defending but not when prosecuting - the courts invoke the theory of sovereign immunity. Because the sovereign must consent to any suit

31. Sec, e.g., United States v. Nixon, 418 U.S. 683, 703-16 (1974).

32. See, e.g., Roviaro v. United States, 353 U.S. 53, 60-61 (1957).

33. See, e.g., United States v. Nixon, 418 U.S. 683, 703-16 (1974) (executive privilege must give way to need for information in criminal prosecution); Roviaro v. United States, 353 U.S. 53, 60-61 (1957) (informer's privilege requires balancing interests in secrecy and disclosure).

34. See, e.g., United States v. Reynolds, 345 U.S. 1, 11 (1953) (state secrets privilege is absolute); Halkin v. Helms, 598 F.2d 1, 7 (D.C. Cir. 1978) (same); Sigler v. LeVan, 485 F. Supp. 185, 193 (D. Md. 1980) (same).

35. See American Civil Liberties Union v. Brown, 619 F.2d 1170, 1173-75 (7th Cir. 1980) (en banc) (approving in camera review of evidence essential to prove plaintiffs' claims).

36. See Pan Am. World Airways, Inc. v. Aetna Cas. \& Sur. Co., 368 F. Supp. 1098, 1140-41 (S.D.N.Y. 1973), affd on other grounds, 505 F.2d 989 (2d Cir. 1974).

37. United States v. Reynolds, 345 U.S. 1, 12 (1953); Jabara v. Kelley, 75 F.R.D. 475, 481 (E.D. Mich. 1977); see Halkin v. Helms, 598 F.2d 1, 7-10 (D.C. Cir. 1978) (privilege "absolute," requiring dismissal of action when privileged information necessary to proceed); Sigler v. LeVan, 485 F. Supp. 185, 192-94 (D. Md. 1980) (dismissing action when relief requested would result in disclosing state secrets).

38. See Jencks v. United States, 353 U.S. 657, 671 (1957) (government may invoke privileges in criminal case only at price of freeing defendant); Attorney Gen. v. Irish People, Inc., 502 F. Supp. 63, 67 (D.D.C. 1980) (dismissing prosecution under Foreign Agents Registration Act, 22 U.S.C. \$§ 611618 (1976), because government withheld privileged documents).

39. See United States v. Reynolds, 345 U.S. 1, 12 (1953). 
against it, the courts reason, the sovereign may set the terms of the suit. ${ }^{40}$ The courts infer that one of the terms of the waiver of immunity is the free use of the privilege.

\section{B. The Privilege Applied: The Surveillance Cases}

The state secrets privilege has recently emerged as a significant impediment to discovery. ${ }^{41}$ Two reasons account for its increased prevalence. The first is the expansion, since World War II, of the factors considered relevant to national security. Throughout the first half of this century, the executive claimed the privilege for military data only. ${ }^{42}$ In the current international setting, however, matters as diverse as international trade, manufacturing techniques, natural resource supplies, social unrest, and even meteorological conditions can affect national security. ${ }^{43}$ Thus the scope of information arguably protected by the privilege has grown dramatically.

The second factor in the privilege's emerging significance is the increased use of civil litigation to protect individual rights from intentional abuses of executive power. In the past two decades, both the courts and Congress have enlarged the role of private damage suits to control and to remedy knowing executive invasions of personal freedoms. The courts have established that violations of constitutional restraints may render government agents liable in tort actions. ${ }^{44}$ Congress has expanded the Federal Tort Glaims Act to create government liability for certain constitu-

40. See id.

41. The executive has invoked the privilege in government misconduct litigation. See, eg., Hormon v. Kissinger, No. 77-1748 (D.D.C. filed Oct. 6, 1977) (alleging deprivation of life without due process); supra note 3 (citing cases). The privilege also arises in commercial litigation. See, e.g., Farnsworth Cannon, Inc. v. Grimes, 635 F.2d 268, 269 (4th Cir. 1980) (wrongful interference with prospective contractual relations); Pan Am. World Airways, Inc. v. Aetna Cas. \& Sur. Co., 368 F. Supp. 1098, 1139-41 (S.D.N.Y. 1973), affd on other grounds, 505 F.2d 989 (2d Cir. 1974) (insurance coverage for airplane destroyed by terrorists). Privilege claims also obstruct criminal prosecutions. See United States v. Felt, 502 F. Supp. 74, 75-77 (D.D.C. 1980) (prosecution of FBI agents for illegal surveillance). Congress recently addressed the problems that occur when defendants seek to introduce classified materials in criminal trials. See Classified Information Procedures Act, Pub. L. No. 96-456, 94 Stat. 2025 (1980) (to be codified at 18 U.S.G. App.).

42. See, e.g., Firth Stirling Steel Co. v. Bethlehem Steel Co., 199 F. 353, 355 (E.D. Pa. 1912) (weapons blueprints); Cresmer v. United States, 9 F.R.D. 203, 204 (E.D.N.Y. 1949) (permitting discovery of Navy Board of Investigations report in absence of military secrets). The leading, and perhaps only, nineteenth-century case that involved this privilege concerned military espionage. See Totten v. United States, 92 U.S. 105, 107 (1875) (action on contract for wartime spying).

43. See, e.g., Halperin v. Kissinger, 606 F.2d 1192, 1201 (D.C. Cir. 1979), aff'd by equally divided court, 101 S. Ct. 3132 (1981) (national security affected by many factors); Note, supra note 26, at 409-1l (describing post-World War II expansion of concept of national security).

44. See, e.g., Garlson v. Green, 446 U.S. 14 (1980) (tort liability for Eighth Amendment violation); Bivens v. Six Unknown Named Agents, 403 U.S. 388 (1971) (tort liability for Fourth Amendment violation); Schuck, Suing Our Servants: The Court, Congress and the Liability of Public Officials for Damages, 1980 SUP. CT. REV. 281, 283-87, 316-38 (current state of liability and immunity rules applicable to official misconduct). 
tional violations..$^{45}$ In addition, Congress has authorized damage actions for violations of several new statutes that protect personal rights. ${ }^{46}$

Recent suits that have alleged illegal surveillance of political activists ${ }^{47}$ demonstrate the increased cost of the state secrets privilege. To deter or remedy intentional rights violations through private causes of action, plaintiffs must be able to obtain evidence concerning the executive's alleged misconduct. Frequently, this evidence is in the executive's exclusive possession. If it has intentionally violated the plaintiffs' rights, the executive is unlikely to release voluntarily inculpatory information. Judicial supervision ordinarily protects the plaintiffs' discovery rights against such manipulation. The courts' current interpretation of the state secrets privilege, however, has allowed the executive to withhold evidence and to defeat misconduct claims.

The courts have permitted this result by mechanically following the procedures outlined in Reynolds, without accounting for differences between the circumstances of Reynolds and those of the surveillance cases. ${ }^{48}$

45. See 28 U.S.C. $\S 2674$ (1976) (United States liable in tort, with certain restrictions, to same extent as private individual). An individual can sue the United States for constitutional torts "only if the State in which the alleged misconduct occurred would permit a cause of action for that misconduct to go forward." Carlson v. Green, 446 U.S. 14, 23 (1980); see Brown v. United States, 653 F.2d 196, 201 (5th Cir. 1981) (damages not available under Federal Tort Claims Act for malicious prosecution instigated by FBI agent because state would not impose liability for false testimony given without malice to grand or petit juries). This obstacle should not pose an insurmountable hurdle in surveillance cases because such unconstitutional intrusions could form the basis for liability as a common-law tort of invasion of privacy. See Bimbaum v. United States, 588 F.2d 319, 323-28 (2d Cir. 1978).

46. Sec, c.g., Omnibus Crime Control and Safe Streets Act of 1968, § 802, 18 U.S.C. § 2520 (1976) (amending and expanding basis for liability for illegal surveillance under the Federal Communications Act of 1934, $\S 605,47$ U.S.C. $\S 605$ (1976) (creating cause of action for damages against anyone who intercepts, discloses, uses, or procures anyone else to intercept, disclose, or use, wire or oral communications in violation of Act)). Section 3 of the Privacy Act of 1974 provides a cause of action against the United States if any federal agency maintains files on a person's exercise of First Amendment rights. 5 U.S.C. § 552a, (e)(7), (g)(4) (1976); see Jabara v. Kelley, 476 F. Supp. 561, 581 (E.D. Mich. 1979) (Privacy Act forbids maintenance of records concerning contents of speeches by individual, even when records obtained in course of legitimate security investigation, unless focused on past or anticipated specific criminal act).

47. Sec, e.g., Halkin v. Helms, 598 F.2d 1 (D.C. Cir. 1978) (suit by anti-Vietnam war activists against officials of CIA and NSA); Alliance to End Repression v. City of Chicago, 91 F.R.D. 182 (N.D. Ill. 1981) (suit by political organizations and members alleging unlawful infiltration, surveillance, and harrassment); Socialist Workers Party v. Attorney Gen., 463 F. Supp. 515 (S.D.N.Y. 1978) (same). These cases have been stimulated, in part, by public revelations concerning the executive's systematic use of forbidden surveillance techniques-including warrantless wiretapping and mail opening -in its investigations of political dissidents. See, e.g., F. DONNER, THE AGE OF SURVEILLANCE (1980). Several official investigations document the surveillance programs challenged in the litigation. E.g., SENATE SELECT COMM. TO STUDY GOVERNMENTAL OPERATIONS WITH RESPECT TO INTELLIGENCE ACTIVITIES, SUPPLEMENTARY DETAILED STAFF REPORTS ON INTELLIGENCE ACTIVITIES AND THE RIGHTS OF AMERICANS, BOOK III, S. REP. NO. 755, 94th Cong., 2d Sess. (1976) [hereinafter cited as BOOK III]; COMMISSION ON CIA ACTIVITIES WITHIN THE UNITED STATES, REPORT TO THE PRESIDENT (1975). The recent creation and expansion of damage remedies for targets of illegal surveillance have facilitated these actions. See supra notes 44-46.

48. See, e.g., Halkin v. Helms, 598 F.2d 1, 9 (D.C. Cir. 1978) (applying Reynolds procedures); Sigler v. LeVan, 485 F. Supp. 185, $192-94$ (D. Md. 1980) (same); Kinoy v. Mitchell, 67 F.R.D. 1, 9 (S.D.N.Y. 1975) (same). 
In Reynolds, the executive was not suspected of intentionally invading the plaintiffs' rights or of using the privilege to defeat the plaintiffs' case. The Supreme Court upheld the privilege to protect military technology secrets ${ }^{49}$ after the Secretary provided an alternative source for the information sought by the plaintiffs.

In the typical surveillance case, by contrast, there is reason to suspect that the executive has invoked the privilege to defeat the plaintiffs' suit. The executive has relied on an expanded concept of national security to deny discovery of information that is insufficiently sensitive to require the absolute protection accorded by the privilege..$^{50}$ In addition, the executive has withheld crucial information unavailable from other sources. ${ }^{51}$ The loss of this evidence seriously impedes or even forecloses the plaintiffs' case. Applied in this way, the privilege permits the executive not only to safeguard a broad class of national security information, but also to minimize liability incurred for invasions of personal rights.

\section{Inadequacies in Judicial Evaluations of State Secrets Privilege Claims}

The evaluation of the state secrets privilege presents the judiciary with two competing considerations. Courts hesitate to probe executive decisions concerning international affairs ${ }^{52}$ because of judicial deference to the President's constitutional responsibility for foreign policy, ${ }^{53}$ and judicial recognition that the executive has superior skills for making those policy judgments. ${ }^{54}$ In conflict with this reluctance is the need for judicial supervision

49. See United States v. Reynolds, 345 U.S. 1, 11 (1953) (secret electronic equipment in warplanc). Although the Reynolds opinion refers to a privilege that protects both military and state secrets, the part of the opinion setting down rules for use of the privilege refers only to military secrets. Id. at 11 .

50. The information sought in the surveillance cases has often been related to domestic intelligence activities widely assumed to occur, or otherwise not surprising to the public. See American Civil Liberties Union v. Brown, 619 F.2d 1170, 1173-74 (7th Cir. 1980) (en banc) ("very general intelligence techniques"); Halkin v. Helms, 598 F.2d 1, 4-5 (D.C. Cir. 1978) (interception of overseas communications); Affidavit and Formal Claim of Privilege of Attorney General Griffin Bell, Kinoy v. Mitchell, No. 70-5698 (S.D.N.Y. Feb. 9, 1979). (wiretapping offices of Communist Party, United States of America, and of foreign embassies). Technical weapons data such as that in Reynolds are rarely, if ever, involved.

51. See, e.g., Jabara v. Kelley, 75 F.R.D. 475, 486 (E.D. Mich. 1977).

52. See, e.g., Goldwater v. Carter, 444 U.S. 996, 997 (1979) (Powell, J., concurring) (dispute between Congress and President concerning treaty termination not amenable to judicial resolution); Chicago \& S. Air Lines v. Waterman S.S. Corp., 333 U.S. 103, 111 (1948) (decisions concerning foreign air transportation require evaluation of secret information and of political ramifications, and therefore are inappropriate subject for judicial review).

53. See U.S. CONST. art. II, $\S 2$ (President is commander-in-chief of armed forces and is authorized to make treaties and to appoint ambassadors). Congress also has substantial powers for creating foreign policy. See id. (presidential authority restricted by senatorial consent requirement); id. art. I, $\S$ 8 (Congress authorized to regulate foreign commerce and to declare war).

54. See, e.g., Halkin v. Helms, 598 F.2d 1, 8-9 (D.C. Cir. 1978) (inappropriate for courts to challenge executive's judgment when national security involved). The Supreme Court has implied that the courts do have a role, albeit narrow, in international affairs that involve questions of international 
of evidentiary privileges to prevent their use as a shield against liability. A failure to supervise can lead to encroachment on constitutional rights by the executive.

\section{A. The Need for a More Comprehensive Inquiry}

The current procedures for the review of privilege claims do not adequately reconcile these opposing interests. The courts' reliance on the prejudicial impact test to distinguish information that requires protection evaluates only one variable: potential harm to national security. The courts ignore the extent of probable harm, the litigants' need for discovery, or routine executive disclosure practices. ${ }^{55}$ This one-dimensional test is applied in conjunction with the courts' broad conception of national security. As a result, almost any information can qualify as privileged because almost any information-economic, demographic, even meteorological-if disclosed, could be useful to a foreign adversary and potentially prejudicial to the nation's security. ${ }^{56}$

By relying on prejudicial impact as the sole criterion for evaluating privilege claims, the courts, in effect, have no standard for identifying information that truly requires protection. ${ }^{57}$ Because they lack an effective standard and hesitate to override executive decisions that concern foreign affairs, the courts rely primarily on executive determinations of the need for secrecy. The executive's claim thus becomes a presumption, practically irrebuttable, of privilege that renders review of such claims perfunctory. Privilege claims made in some surveillance cases indicate that the executive has exploited this opportunity to defeat allegations of misconduct by protecting information of minimal security value. ${ }^{58}$

The prejudicial impact test also preempts judicial scrutiny of factors

law. See Banco Nacional de Cuba v. Sabbatino, 376 U.S. 398, 428 (1964) (under certain circumstances, federal courts may incorporate international law into domestic law).

55. See supra pp. 574-75 (describing prejudicial impact test).

56. See, e.g., Halperin v. Kissinger, 606 F.2d 1192, 1201 (D.C. Cir.1979), aff'd by equally divided court, 101 S.Ct. 3132 (1981) (security interests affected by international trade, supply of natural resources, social unrest, and disclosure of policy deliberations); Zagel, supra note 26, at 891 ("II]t is hard to imagine a case in which the Government cannot plausibly argue that military secrets are at stake."); jd. at 898 (government withheld report on bow and arrow weapon); Note, supra note 26, at 409-15 (national security depends on all national resources).

57. See Zagel, supra note 26 , at 882 ("The courts have not developed meaningful standards for evaluating state secrets.") Proponents of the prejudicial impact test may contend that all security interests require nondisclosure. Such an argument, however, entails untenable consequences. Disseminating almost any information not already officially disclosed can present some danger to national security. See supra note 56. Therefore, supporters of the prejudicial impact test commit themselves to allowing the executive to withhold any information it desires. The Reynolds Court clearly rejected such an unregulated privilege. See United States v. Reynolds, 345 U.S. 1, 9-10 (1953).

58. See supra note 50 . Of course, on other occasions the executive does apply the privilege to concededly sensitive documents for which it has legitimate security concerns. See Sigler v. LeVan, 485 F. Supp. 185, 192-94 (D. Md. 1980) (classified documents about U.S. counterintelligence activities). 
that suggest that, even if discovery threatens security, disclosure might be warranted. The executive has regularly released information, despite its sensitivity, in a variety of settings. ${ }^{59}$ If these disclosures are limited and are not made officially to the public, valid security reasons may underlie subsequent withholding of the information from the litigants. ${ }^{60}$ The executive has also circulated publicly sensitive information. ${ }^{61}$ These disclosures, restricted or public, promote different interests-such as administrative convenience, law enforcement, rebuttals to political opponents, and defense of the government in judicial proceedings. ${ }^{62}$ The executive, however, routinely asserts the need to guard security related data when litigants seek discovery against it. ${ }^{63}$. Focusing solely on possible prejudicial impact, the courts sustain the privilege without considering the extent or circumstances of disclosures of similar sensitive information. ${ }^{64}$ One court even upheld a privilege claim despite the release of the same information in another litigation..$^{5}$

A more comprehensive test is needed to enable courts to differentiate bona fide claims made to protect national security from those that, although superficially genuine, are intended in fact to promote other executive interests. The executive's ability to demonstrate security risks when it opposes discovery does not mean necessarily that the executive is resisting discovery to avoid those dangers. Executive willingness, in some contexts, to offset security concerns by factors such as political survival or adminis-

59. See, e.g., Halperin v. Department of State, 565 F.2d 699, 701 (D.C. Cir. 1977) (sensitive information routinely disclosed in press background briefings); 42 U.S.C. \$ 2161 (1976) (permitting and encouraging dissemination of atomic energy technology to promote scientific and industrial progress and public understanding); see Zagel, supra note 26, at 879 (disclosure of military technology necessary to promote further weapons research and development).

60. See, e.g., Halkin v. Helms, 598 F.2d 1, 9 (D.C. Cir. 1978) ("The government is not estopped from concluding in one case that disclosure is permissible while in another case it is not."); Halperin v. Department of State, 565 F.2d 699, 704, 706-07 (D.C. Gir. 1977) (disclosure in press briefing not for attribution to government; revealing government as source may indicate intelligence abilities or methods).

61. The controversy surrounding the Carter administration's revelations of the development of the Stealth aircraft focused on the President's use of the disclosure as a rebuttal to opposition candidates' claims that the nation's military strength had eroded under Carter's stewardship. See Stealth, WASHINGTON POST, Sept. 7, 1980, \& D, at 6 (editorial); Recipient of Leak on 'Stealth' Calls It a Political Move, WASHINGTON POST, Aug. 28, 1980, § A, at 2.

62. See Halperin v. Department of State, 565 F.2d 699, 701 (D.C. Cir. 1977) (to inform public of events of political significance); Firemen's Fund Indem. Co. v. United States, 103 F. Supp. 915, 916 (N.D. Fla. 1952) (to defend in litigation).

63. See supra p. 576 (circumstances in which state secrets privilege claim arises).

64. See supra pp. 574-75 (evaluation of claims with prejudicial impact test). The courts sometimes review the information to determine if there has been official public disclosure, but the courts disagree over what constitutes official public disclosure. Compare Jabara v. Kelley, 75 F.R.D. 475, 493 (E.D. Mich. 1977) (ordering disclosure of name of federal agency that intercepted plaintiff's communications after Senate report named agency) with Halkin v. Helms, 598 F.2d 1, 9 (D.C. Cir. 1978) (revelation in Senate report and in Jabara v. Kelley of National Security Agency surveillance activities does not prevent agency from refusing either to admit or to deny surveillance of plaintiff).

65. Halkin v. Helms, 598 F.2d 1, 9 (D.C. Cir. 1978). 
trative convenience indicates that the threat of harm from disclosure does not necessarily determine the decision to withhold or not to withhold the information. Many threats to security are sufficiently improbable or inconsequential to be outweighed by the benefits from disclosure. The executive, however, will undoubtedly undervalue some important private and public interests and rely on security interests as a refuge from accountability. As long as prejudicial impact is the sole measure of the state secrets privilege, courts cannot strip the executive of this shield. ${ }^{66}$

\section{B. The Need for More Varied Responses to Legitimate Privilege Claims}

The surveillance cases also illustrate that the state secrets privilege can neutralize constitutional constraints on executive powers. ${ }^{67}$ When the courts face a valid privilege claim, the Constitution poses a dilemma: the courts must respect the executive's constitutional responsibility to protect national security interests; they also, however, must enforce constitutional as well as congressional constraints on executive powers. ${ }^{68}$ In resolving this dilemma, the judiciary should recognize that, although ours is a government of separated powers, it also is one in which the powers of each branch check and balance one another. ${ }^{69}$ The judiciary can best harmonize

66. The loss of evidence and subsequent frustration of plaintiffs' claims is particularly disturbing when the executive invokes the privilege after disclosures that produce evidence that supports the allegations of illegal surveillance. See, e.g., Jabara v. Kelley, 75 F.R.D. 475, 485 (E.D.Mich. 1977) (defendants admitted intercepting conversations of plaintiff in warrantless wiretaps); Kinoy v. Mitchell, 67 F.R.D. 1, 5 (S.D.N.Y. 1975) (same). The government often contends that the plaintiffs were not targets of the surveillance, but were merely "overheard incidental to national security intelligence investigations of other persons." Id. The fact that the interception was incidental does not necessarily negate liability for the surveillance or subsequent use of the information obtained. See id. at 12.

To establish their right to a remedy, the plaintiffs must overcome several obstacles in addition to demonstrating that the government monitored their activities. Certain surveillances are lawful if the exccutive obtains prior judicial approval. See, e.g., United States v. United States Dist. Court, 407 U.S. 297, 317-18 (1972) (discussing warrant requirement). If the executive acted without a warrant, the courts still may find the surveillance permissible because of the exigencies of national security. Compare id. at 32l-23 (reserving opinion on whether electronic surveillance of foreign powers or their agents requires prior judicial approval) with Zweibon v. Mitchell, 516 F.2d 594, 651 (D.C. Cir. 1975), (implying that if any national security exception exists, it is extremely narrow) cert. denied, 425 U.S. 924 (1976). Even if the surveillance did violate the law, the executive may assert reasonableness or good faith defenses. Id. at 670-73.

67. See Halkin v. Helms, 598 F.2d 1, 13-14 (D.C. Cir. 1978) (Bazelon J., dissenting) (privilege has become "a shield behind which the government may insulate unlawful behavior from scrutiny and redress by citizens who are the target of the government's surveillance"); supra note 66 (loss of evidence from privilege may impede or foreclose plaintiff's case).

68. The courts have affirmed the importance of their role in enforcing restrictions on the executive's surveillance activities even when national security is implicated. See United States v. United States Dist. Court, 407 U.S. 297, 313-14, 317, 321 (1972) (prior judicial approval required for "some" clectronic security surveillances, including those for enforcement of espionage and sabotage laws). Use of the privilege in surveillance cases is analogous to the warrant issue in which the executive's responsibility to protect the national security conflicts with the judiciary's responsibility to protect individuals' constitutional or statutory rights. See Halkin v. Helms, 598 F.2d 1, 12-13 (D.C. Cir. 1978) (Bazelon, J., dissenting).

69. See Nixon v. Administrator of Gen. Servs., 408 F. Supp. 32l, 342 (D.D.C. 1976), aff'd, 433 
these constitutional demands by minimizing the impact of legitimate privilege claims-either by applying only those restrictions necessary to protect valid security interests or by compensating when possible for the loss of evidence. ${ }^{70}$

The judicial response to valid privilege claims is ordinarily limited to a simple denial of discovery. ${ }^{71}$ The courts usually do not attempt to minimize the impact of those claims and thereby ignore their constitutional obligation to enforce substantive controls on executive powers. They usually overlook judicial techniques-such as protective orders or in camera proceedings-that would satisfy security needs while permitting restricted access to relevant information..$^{72}$ The use of such techniques as part of a judicial policy of impact minimization would permit the executive to protect legitimate national security interests while preserving constitutional and statutory protections against abuse of those powers.

Furthermore, under current practice the courts disregard evidence lost by privilege claims except when the government prosecutes. This practice often prevents the plaintiffs from proceeding with their case. ${ }^{73}$ The courts make no attempt to correct for the loss by, for example, employing infer-

\section{U.S. 425 (1977).}

70. The courts traditionally require the government to adopt the least restrictive means available to achieve government interests when the pursuit of those interests burdens constitutionally protected rights. See P. BREST, PROCESSES OF CONSTITUTIONAL DECISIONMAKING 990-94 (1975). At times, even the least restrictive means impose too great a burden on individual rights to permit their use. The courts apply this requirement to their evaluation of privilege claims by limiting the scope of a privilege to that information it was designed to protect. See United States v. Nixon, 418 U.S. 683, 709-10 (1974) (privileges construed narrowly to permit broadest possible discovery consistent with purposes of each privilege). In extending this requirement to regulate its responses to valid privilege claims, the judiciary should recognize that a privilege can be sustained by a variety of techniques, and that techniques should not be chosen that burden litigants' rights more than alternative techniques.

When the privilege claim impinges on individually enforceable congressional controls on executive activities, separation of powers considerations exist. By restricting access under a valid privilege claim only to the extent necessary to protect secrecy needs, the court limits the effect of executive actions to those necessary to fulfill the executive's constitutional duty. See Nixon v. Administrator of Gen. Servs., 408 F. Supp. 32l, 342 (D.D.C. 1976), aff'd, 433 U.S. 425 (1977).

71. See supra p. 575.

72. In recognizing their authority to order in camera submission of sensitive material, courts have noted the distinction between the dangers of public disclosures and those posed by restricted disclosures. E.g., Zweibon v. Mitchell, 516 F.2d 594, 625 n.80 (D.C. Cir. 1975), cert. denied, 425 U.S. 944 (1976). Some courts have used techniques that restrict disclosure in order to permit litigation to proceed on some occasions-for example, when both parties possessed the allegedly privileged information. In Halpern v. United States, an action by an inventor for damages that allegedly occurred from an order of secrecy involving his application for a patent, the Second Circuit Court of Appeals approved a district court order for an in camera trial. 258 F.2d 36 (2d Cir. 1958). The court relied, in part, on the fact that the plaintiff was not seeking to obtain secret information he did not know. Id. at 44. Another court referred a contract dispute between two manufacturers of classified United States Air Force equipment to a special master. Loral Corp. v. McDonnell Douglas Corp., 558 F.2d Il30 (2d Cir. 1977). The Department of Defense had objected to a jury trial because the material involved in the dispute was confidential. Id. at 1132; see Firth Stirling Steel Co. v. Bethlehem Steel Co., 199 F.2d 353, 354-56 (E.D. Pa. 19l2) (executive may invoke privilege to expunge record of exhibit containing munitions plans).

73. See supra p. 575. 
ences, or shifting the burdens of persuasion. As a result, the executive can rely on its security interests to shield its misconduct.

The courts in approving this asymmetrical approach-although the executive cannot freely use the privilege when prosecuting, it may do so when defending-have misapplied the theory of sovereign immunity. Congress, not the executive, has waived sovereign immunity through the Federal Tort Claims $\mathrm{Act}^{74}$ and other statutes that specifically authorize suits against the United States or its officers. ${ }^{75}$ This waiver does not authorize the executive to set the terms for the litigation. To do so would effectively undermine controls on the exercise of its powers. Because Congress has created a statutory right of action, the fact of the waiver of immunity justifies limiting the privilege when necessary to preserve constitutional or statutory restraints on the executive. ${ }^{76}$

III. Proposals for Improving the Evaluation of and the Response to Privilege Claims

When evaluating a privilege claim, the courts should replace the prejudicial impact test with a comparative standard that considers the sensitivity of the information sought, the litigants' need for the information, and the executive's treatment of such information in the past. Unlike the prejudicial impact test, the comparative standard would enable the judiciary to ensure that the executive invokes its security interests reasonably and fairly. In addition, if under the comparative standard the courts uphold a privilege claim, they should formulate a discovery order that preserves both the executive's obligation to protect national security and the court's

74. See 28 U.S.C. $\$ 2674$ (1976) (United States is liable in tort, with certain restrictions, to same extent as private individual); cf. supra note 45 (discussing availability of Federal Tort Claims Act remedies for violations of constitutionally protected rights).

75. See supra note 46 (citing statutes authorizing suits against officers of United States).

76. The courts apply such limits to protect liberty interests when the government prosecutes. See, e.g., Jencks v. United States, 353 U.S. 657, 669-72 (1957) (if government suppressses evidence pertaining to criminal proceedings, it must discontinue prosecution); Attorney Gen. v. Irish People, Inc., 502 F. Supp. 63, 67 (D.D.C. 1980) (same). They have noted that the liberty interests involved in security surveillance cases are among those most highly valued and that judicial protection of those liberties is essential to their preservation. See, e.g., Halperin v. Kissinger, 606 F.2d 1192, 1199-1201 (D.C. Cir. 1979), affd by equally divided court, 101 S. Ct. 3132 (1981). In addition, the courts have an obligation, rooted in the separation of powers, to defend congressional lawmaking prerogatives against the exercise of excessive presidential powers. See Youngstown Sheet \& Tube Co. v. Sawyer, 343 U.S. 579, 585-89 (1952). Rather than preserve the congressional desire that individual rights be enforceable by private actions in federal courts, the judiciary has frustrated that desire by ignoring the evidence lost by the privilege. Cf. 2 J. WEINSTEIN \& M. BERGER, supra note 4, I 501[02] at 509-20 (Advisory Committee draft of proposed rule governing use of privilege in Federal Rules of Evidence directed courts to make any further order that interests of justice require when privilege claim deprives party of material evidence). 
own obligation to enforce constitutional and statutory restraints on executive activities. ${ }^{77}$

\section{A. Beyond Prejudicial Impact: The Use of a Comparative Standard}

Because under the prejudicial impact test virtually any information can qualify as privileged, it provides inadequate restraints on the executive's use of the privilege. To guard against the use of the privilege to manipulate evidence, the courts should not consider information to be privileged solely because of its potential prejudicial impact; instead, they should determine whether the danger from discovery conducted under conditions imposed by the court ${ }^{78}$ warrants withholding the information despite its disclosure value.

Such a comparative standard underlies government secrecy decisions on a variety of national security related information. For example, until recently executive classification decisions considered both the sensitivity and the advantages of disclosure. ${ }^{79}$ If the executive can recognize that the advantages of publicity from disclosure outweigh the potential prejudice to national security, the courts can do so as well.

Unlike the prejudicial impact test, the comparative standard would provide the courts with a means to distinguish cases in which security interests require nondisclosure from cases in which they do not. The comparative standard would replace the low threshold of prejudicial impact with a variable standard that would permit nondisclosure only if the dangers of discovery actually outweigh its benefits.

Other tests could also provide the courts with a basis for identifying circumstances that require nondisclosure, but the comparative standard

77. Although the proposals set forth in this Note are directed at the judiciary, judicial change is not necessarily the exclusive avenue of remedy. Congress could enact restrictions on the executive's use of the privilege as was proposed for the Federal Rules of Evidence. See $2 \mathrm{~J}$. WEINSTEIN \& M. BERGER, supra note 4, I 501[02], at 501-17. The courts, however, must ultimately enforce any restrictions on privilege claims. The current problem stems more from undue judicial deference to the executive than from the unavailability of a legal standard that courts could apply. See supra pp. 579-83. Judicial awareness of the inadequacies of the current evaluations of state secrets privilege claims should encourage a more appropriate judicial response.

78. See infra pp. 587-88 (under certain circumstances courts should permit limited discovery through protective orders, in camera inspection, or document summaries).

79. Exec. Order No. 12,065, § 3-303, 43 Fed. Reg. 28,949, 28,955 (1978), repealed by Exec. Order No. 12,356, 47 Fed. Reg. 14,874 (1982) (information should be declassified when public interest in disclosure outweighs need to protect such information); $c f$. Alfred A. Knopf, Inc. v. Colby, 509 F.2d 1362, 1369 (4th Cir. 1975) (information is sometimes declassified by executive decision that disclosure is in public interest) cert. denied, 421 U.S. 1000 (1975). Congress has also recognized that secrecy decisions must compare the value of disclosure with that of nondisclosure. See Atomic Energy Act of 1954, § 1, 42 U.S.C. § 2161 (1976) (declassification of data concerning production and use of nuclear weapons and materials encouraged to promote scientific progress and public understanding). See generally Zagel, supra note 26, at 877-85 (determining whether information should be kept confidential to promote national security requires balancing of interests). 
test has certain advantages. For example, courts could apply a straight sensitivity test, which would withhold only information that is properly classified or information that presents a certain threshold level of danger to national security - a level higher than prejudicial impact. Reliance on executive classification standards, however, presents the problem of unregulated executive control over discovery. Given the executive's tendency to overclassify, such a standard would likely be abused..$^{80}$ The proposed comparative standard is preferable, because it more accurately captures the purpose of the privilege and reflects the relativity inherent in the concept of informational secrecy. ${ }^{81}$

Such review would not require the courts to perform evaluative tasks beyond their competence. Although security issues are complex, the complexity is no greater than that commonly faced by the courts. ${ }^{82}$ The courts must perform a similar task, under the FOIA, in reviewing executive claims that material is exempt from disclosure because of its potential harm to security. ${ }^{83}$ If a threat is too subtle or complex for the executive to convince a court of its significance, there is reason to doubt the existence

80. Cf. Zagel, supra note 26 , at 898 (executive classification of report that water runs downhill). Reliance solely on classification would create the anomalous situation that the executive could deny discovery for information disclosable under the FOIA. See supra note 4 (FOIA exempts from disclosure only information that is properly classified and that must remain secret in interests of national security).

81. See supra pp. 579-81, 584 n.79 (sometimes disclosure necessary despite sensitivity); E. CLEARY, supra note l, at 230 (need to balance public interest in secrecy with public interest in protecting litigants' due process rights).

This comparative test should not be confused with the weighing of interests courts currently do undertake. Courts vary their scrutiny of a state secrets privilege claim according to the plaintiff's showing of need for the allegedly privileged information. But under the prejudicial impact test, a plaintiff's need, however compelling, can never overcome any security interest, however minimal. Compelling need serves only to ensure that the court scrutinizes a privilege claim to be certain that discovery would reveal some state secret. See supra pp. 574-75.

82. United States v. United States Dist. Court, 407 U.S. 297, 32l (1972).

83. 5 U.S.C. $\$ 552(\mathrm{a})(4)(B),(b)(1)$ (1976) (court must determine de novo whether information is exempt from disclosure because information is properly classified and must remain secret in interest of national security); see Ray v. Turner, 587 F.2d 1l87, 1191-95 (D.C. Cir. 1978) (describing de novo review procedures required by FOIA). Central to this review should be use of Vaughn-type indices, under which the executive identifies the material as specifically as consistent with security needs, explains the danger likely to attend disclosure, and provides reasons why that danger would occur. See Vaughn v. Rosen, 484 F.2d 820, 826-28 (D.C. Cir. 1973) (outlining proposed form of affidavit and index that would aid court making disclosure decision) cert. denied, 415 U.S. 977 (1974).

The FOIA sets a minimum standard for disclosure in the absence of particularized need, see 5 U.S.C. § 552(a) (1976) (disclosure to "any person"); McLelland v. Andrus, 606 F.2d 1278, 1287 (D.C. Cir. 1979); in applying the proposed comparative standard, however, a court would consider whether the value of disclosure in the context of the litigation outweighs the need for continued secrecy. The FOIA standard is similar to the prejudicial impact test in that the FOIA exempts all classified information that must remain secret to protect any national security interest. See 5 U.S.C. $\S$ 552(b)(1) (1976) (exempting from disclosure information that is properly classified and that must remain secret in interest of national security). Under the comparative test, the courts could order discovery when the litigant's need outweighs security interests. Because the FOIA establishes a general right of access in the absence of need, it has no provision for release of classified information once the executive establishes some security interest. 
of the alleged danger. ${ }^{84}$ As in the FOIA context, the courts should accord weight to the executive's "unique insights into what adverse affects [sic] might occur as a result of public disclosure." ${ }^{\prime 35}$ The courts, however, are competent to weigh the dangers perceived by that executive insight against the value of disclosure. ${ }^{86}$

The courts should also scrutinize the limited disclosures that are routinely permitted by the executive in order to prevent the executive from selectively asserting its security interests to frustrate discovery. By scrutinizing routine security practices, the courts could determine if the executive has asserted a security need sufficient to justify opposing discovery. ${ }^{87}$ This review would also provide courts with insights into executive disclosure decisions that could guide application of the comparative test. In addition, scrutiny of disclosure practices of the particular information at issue would identify circumstances in which the executive has made information available to government litigators or to one of the parties while unfairly resisting a discovery request of an opposing party. ${ }^{88}$

\section{B. Alternative Responses to Legitimate Security Needs}

The current judicial practice of ignoring the loss of evidence caused by

84. United States v. United States Dist. Court, 407 U.S. 297, 321 (1972).

85. Ray v. Turner, 587 F.2d 1187 , 1194 (D.C. Cir. 1978) (quoting S. REP. No. 1200, 93d Cong., 2d Sess. 12, reprinted in 1974 U.S. CODE CONG. \& AD. NEWS 6285, 6290).

86. See Halkin v. Helms, 598 F.2d 1, 15 (D.C. Cir. 1978) (Bazelon, J., dissenting) (noting judicial expertise in balancing government secrecy needs against individual rights). Acknowledgment of judicial expertise in comparing the value of disclosure versus secrecy is implicit in the judicial power to create evidentiary privileges. The courts frequently must balance the public interest in protecting official information with the value of disclosing that information to protect individual rights. See, e.g., Roviaro v. United States, 353 U.S. 53, 60-61 (1957) (recognition of informer's privilege requires "balancing the public interest in protecting the flow of information against the individual's right to prepare his defense"). Although balancing of interests in state secrets privilege claims would require the courts to develop standards for evaluating the relative dangers to national security from disclosures, a review of executive disclosure practices would allow the court to derive objective standards for this comparison. See Berger \& Krash, supra note 18, at 1462-63.

The fact that the executive has greater expertise in determining informational secrecy needs does not preclude judicial competence in such decisionmaking. See supra note 83. Several factors favor placement of the final decision of the balancing of the privilege claim in the courts. The courts have greater expertise than the executive in weighing the litigant's and the public's interest in discovery. Judicial review will check the executive's tendency to overclassify or to withhold information to hide wrongdoing. Finally, despite the formal assertion of the privilege claim by a cabinet level officer, a subordinate employee frequently makes the actual decision to resist discovery, often based on nonsecurity factors. See supra note 18.

87. Even if the court found that by its standards security interests justified secrecy despite the value of disclosure, the court might find that the executive has disclosed similar information in circumstances comparable to those presented in the litigation. Review of routine disclosure provides a means for determining if this has occurred. The court should not permit the executive to require a greater level of security to release information in the litigation unless the executive can distinguish the prior disclosures, for example, by reference to changed circumstances.

88. Cf. Fireman's Fund Indem. Co. v. United States, 103 F. Supp. 915, 916 (N.D. Fla. 1952) (disclosure of privileged material to government counsel while withholding from plaintiff is inappropriate). 
upholding a privilege claim neglects the courts' duty to enforce constitutional and congressional restraints on executive activities. The courts could fulfill this duty without unduly burdening the executive's ability to protect national security by minimizing the impact of valid privilege claims. Even if the executive has asserted a legitimate interest in preventing official public disclosure, the courts should attempt to make the information available in a restricted form that would satisfy security requirements. ${ }^{89}$ The use of protective orders or in camera proceedings could permit discovery and trial under conditions of reduced risk. ${ }^{90}$ If these restrictive disclosure techniques would not provide adequate protection, courts could attempt to

89. Courts occasionally have used restricted disclosures to make information available for purposes of litigation. See supra note 72. Courts should also consider use of restrictive disclosure techniques that maximize adversarial challenge to privilege claims. By limiting the use of ex parte determinations of privilege claims, courts would gain the benefits of an adversarial presentation of the interests at issue. See Ray v. Turner, 587 F.2d 1187, 1205, 1212 (D.C. Cir. 1978) (Wright, C.J., concurring) (encouraging use of restricted disclosures, including in camera access by plaintiff's counsel to contested documents, to resolve disputed FOIA requests). Permitting counsel access to material, but forbidding communication to clients, may be objectionable on other grounds. See Comment, Spying and Slandering: An Absolute Privilege for the CIA Agent? 67 ColUM. L. REV. 752, 771 n.119 (1967) (counsel declined opportunity to examine secret documents in camera because examination conditioned on promise of nondisclosure to client).

90. Most courts have refused to compel disclosures under protective orders because of the risk of irremediable damage if the parties violate the protective order. See, e.g., Halkin v. Helms, 598 F.2d 1, 7 (D.C. Cir. 1978); Sigler v. LeVan, 485 F. Supp. 185, 194 (D. Md. 1980). In so doing, they have not considered whether the reduced danger presented by such restricted disclosure is reasonably distinguishable from the dangers presented by the executive's prior and routine limited disclosures. See Halkin v. Helms, 598 F.2d 1, 7 (D.C. Cir. 1978) (NSA not required to distinguish present refusal to disclose fact vel non of interception from prior admissions). In some circumstances, judicial supervision may protect completely against the harms of official public disclosure. If the harm to be avoided is one of diplomatic disruptions that stem from the attribution of remarks to government officials or from the official acknowledgment of government activities, the executive could continue to disclaim publicly the veracity of the private party's allegations even if a party violated the protective order. As long as the corroborating documents were sealed and no copies were permitted, the executive would be insulated from diplomatic harm. CF. Alfred A. Knopf, Inc. v. Colby, 509 F.2d 1371, 1370 (4th Cir. 1975) ("The reading public is accustomed to treating reports from uncertain sources as being of uncertain reliability."), cert. denied, 421 U.S. 1000 (1975); Halperin v. Department of State, 565 F.2d 699, 701 (D.C. Cir. 1977) (State Department press briefings permit dissemination of sensitive information to public without risk of official attribution); Phillippi v. Central Intelligence Agency, 546 F.2d 1009, 1010-11 (D.C. Cir. 1976) (refusal to admit or deny sponsorship of attempt to salvage sunken Soviet submarine, despite widespread press reports of activity). The courts should require the executive to distinguish the dangers posed by its practice of making informal disclosures to the press and those posed by in camera examination under a protective order.

To reduce the risk of a security breach through in camera proceedings, courts could employ court personnel with security clearances. One possible source of such personnel is the department of the executive claiming the privilege. Halpern v. United States, 258 F.2d 36, 43 (2d Cir. 1958). The Supreme Court has made a similar suggestion regarding the application for warrants in national security surveillances. See United States v. United States Dist. Court, 407 U.S. 297, 321 (1972). 
develop a stipulation of facts to permit adjudication. ${ }^{91}$ Special masters with security clearance could also facilitate such accommodations. ${ }^{92}$

On some occasions, no form of restricted disclosure could adequately protect sensitive information. ${ }^{93}$ The courts, however, should not mechanically disregard the consequent loss of evidence as is the present practice; they should consider alternative responses that would compensate the plaintiffs for the loss of evidence. In many cases, compensatory action-such as construing facts in favor of deprived litigants or shifting burdens against the government-may be the only means for the courts to enforce constraints on executive power.

Whether the courts should take such measures would depend on the particular circumstances of each claim. The surveillance cases suggest several appropriate occasions for such compensatory responses. For example, when viewed in the context of the other facts disclosed by discovery, the information produced by the executive to support the privilege claim may itself provide the basis for drawing reasonable inferences in support of a plaintiff's case.94 On other occasions-for example, when a plaintiff has made a prima facie showing of extensive surveillance and the executive

91. The inability of plaintiffs to gain access to relevant information would impinge on their ability to negotiate a stipulation. The courts could order the executive to provide a set of "representative findings" or a "summary of documents" upon which to litigate the claim. Such a summary could detail the particulars of the surveillances in question, but could delete identifying material. See In re Attorney Gen. of United States, 596 F.2d 58, 68-70 (2d Cir. 1979).

92. See FED. R. GIV. P. 53(b) (reference to master permitted on showing of exceptional circumstances). Federal judges do not routinely receive security clearances, but clearances have been made to facilitate adjudication. See Pan Am. World Airways, Inc. v. Aetna Cas. \& Sur. Co., 368 F. Supp. 1098, 1139 (S.D.N.Y. 1973), aff'd on other grounds, 505 F.2d 989 (2d Cir. 1974). Even after giving a security clearance, however, the executive may decline to disclose certain information to the court for its evaluation of the privilege claim. Id. In such circumstances, a special master with a "higher" clearance would provide a means for neutral review. Review by a special master would also permit a preliminary review of a privilege claim with direct reference to the material in issue, without risking compromise of the court through ex parte submissions. See supra note 19. The special master could provide a "summary of documents" to facilitate negotiation of a stipulation of facts, see supra note 91 , or present the court with proposed findings and conclusions, see Loral Corp. v. McDonnell Douglas Corp., 558 F.2d 1130, 1133 (2d Cir. 1977). As with all determinations of privilege claims, the court retains final responsibility for the acceptance or rejection of the master's recommendations. Id.

93. For example, military secrets in wartime, such as the timing and location of attacks, certainly should not be revealed to the courts or to litigants. Commentators have described the scope of justifiable secrecy concerns as narrow. See R. BERGER, supra note 6, at 369 (secrecy may be required " in regard to the character and deployment of certain weapons," "but " almost never" " for information concerning diplomatic affairs) (quoting Charles W. Yost, former United States Ambassador to the United Nations); Zagel, supra note 26, at 884 (only information related to nation's military capabilities can justifiably be kept secret).

94. Such an inference, for example, comports with Congress' concern, expressed in waiving immunity, that constitutional protections against unreasonable searches be enforceable through damage actions against the government. See S. REP. No. 588, 93d. Cong. 1st Sess. 2-3 (1973), reprinted in 1974 U.S. CODE CONG. \& AD. NEWS 2789, 2790-91. It finds further support in congressionally expressed concern that the executive might use its control of information to subvert restraints on executive powers. See 2 J. WEINSTEIN \& M. BERGER, supra note 4, at 509-3 to -5 . 
withholds all evidence necessary to rebut a defense of reasonableness or good faith-a shift in evidentiary burdens may be appropriate. ${ }^{95}$

The judiciary has created the evidentiary burdens of production and persuasion based on many factors, including access to evidence, the costs of incorrect decisions, and the likelihood of one party being in the wrong. Reconsideration of these allocations is warranted in the surveillance cases when the synergetic action of the burdens of proof and of the evidentiary privilege render curbs on executive activities practically unenforceable. By taking such steps to compensate for lost evidence, the judiciary could fulfill its constitutional role with respect to executive secrecy needs and controls on executive action.

95. Newman, Suing the Lawbreakers: Proposals to Strengthen the Section 1983 Damage Remedy for Law Enforcers' Misconduct, 87 YALE L.J. 447, 458-64 (1978) (criticizing current allocation of defenses and burdens of proof in police misconduct actions).

In the surveillance cases, imposition of any burdens on use of the privilege may be inappropriate if defendants are government agents sued in their personal capacity. See, e.g., Halkin v. Helms, 598 F.2d 1, 3, 10-11 (D.C. Cir. 1978) (manifestly unfair to permit presumption to run against individual defendants when executive withholds state secrets). The courts err, however, in taking the private status of the defendants as a necessary fact of the litigation. Individual defendants often serve as nominal defendants to circumvent sovereign immunity restrictions. See, e.g., id. at 3; Kinoy v. Mitchell, 67 F.R.D. 1, 4 (S.D.N.Y. 1975). In such cases, the named individuals do not always face personal liability; the government often provides counsel and indemnifies defendants for any adverse judgment. See Schuck, supra note 44 , at 332 \& nn.180-83, 333 (no general statutory indemnity exists, but many federal tortfeasors are indemnified in practice). If the court decides to penalize executive use of the privilege, it should, of course, ensure that the penalties or any consequent civil liabilities do not result in collateral disabilities, such as loss of employment, for the nominal defendants. 